\title{
Permissions recognition
}

Every effort has been made to trace all the copyright holders but if any have been inadvertently overlooked the publishers will be pleased to make the necessary arrangement at the first opportunity.

The editor and publishers wish to thank the authors and the following publishers who have kindly given permission for the use of copyright material.

Quotes from The Hitchhiker's Guide to the Galaxy by Douglas Adams, (C) 1979 - reproduced with permission of the Licensor through PLSclear.

Quotes from Lucky Jim, Copyright (C) 1953 by Kingsley Amis, used by permission of The Wylie Agency (UK) Limited and The Orion Publishing Group, London.

Quotes from Ending Up, Copyright (C) Kingsley Amis, 1974, used by permission of The Wylie Agency (UK) Limited and Penguin Books Ltd.

Quotes from Jake's Thing, Copyright (C Kingsley Amis, 1978, used by permission of The Wylie Agency (UK) Limited and The Random House Group Ltd (C) 2007.

Quotes from Time's Arrow: or The Nature of the Offence by Martin Amis published by Vintage. Reproduced by permission of The Random House Group Ltd, (C) 2003 and Penguin Random House LLC.

Quotes from The War Against Cliché by Martin Amis, Copyright (C) 2002, Martin Amis, used by permission of The Wylie Agency (UK) Limited.

Quotes from Blackadder the Third, (C) Rowan Atkinson, Richard Curtis, Ben Elton and John Lloyd, reproduced with permission of Berlin Associates, PBJ Management, Phil McIntyre Entertainments and United Agents on behalf of the rights holders.

Quotes from Post Office by Charles Bukowski, Copyright (C) 1971 by Charles Bukowski. Used by permission of HarperCollins Publishers.

Quote from 2001. A Space Odyssey, Copyright (C) Arthur C. Clarke, 1968, New American Library. Reproduced by permission of David Higham Associates on behalf of the rights holder.

Quote from The Wordsworth Book of Intriguing Words, (C) Paul Hellweg, 1995, Ware: Wordsworth Editions Ltd. Reproduced by permission of the author and rights holder Paul Hellweg.

Quote from Highlander (Film script), 1986. Reproduced by permission of Above the Line Agency on behalf of the rights holder.

Quote from Breaking the Law. Lyrics and music: Glenn Tipton/Kenneth Downing/ Robert Halford, (C) Ebony Tree Ltd/Geargate Ltd/Crewglen Ltd/EMI April Music Inc. Published by permission of Sony/ATV Music Publishing Scandinavia/Notfabriken Music Publishing AB.

Quote from Unseen Academicals by Terry Pratchett, published by Corgi. Reproduced by permission of Colin Smythe Ltd and The Random House Group Ltd, C 2014.

Quote from 10 Classic Novels Summed Up in a Single Sentence, (C) 2019. Reproduced by permission of Black Sheep Publishing. 
Quote from The Lord of the Rings: The Fellowship of the Ring, (C J.R.R. Tolkien, 1954. Reprinted by permission of HarperCollins Publishers Ltd.

Quote from The Lord of the Rings: The Two Towers, (C) J.R.R. Tolkien, 1954. Reprinted by permission of HarperCollins Publishers Ltd.

Quotes from A Confederacy of Dunces, (C) John Kennedy Toole, 1980. Reprinted by permission of LSU Press.

Quote from Brideshead Revisited by Evelyn Waugh (Penguin Books 1962, Penguin Classics 2000), Copyright (C) Evelyn Waugh, 1945. Reproduced by permission of Penguin Books Ltd and Hatchett Book Group, Inc.

Quote from Scoop by Evelyn Waugh (Penguin Books 1943, Penguin Classics 2000), Copyright $(C$ Evelyn Waugh, 1938. Reproduced by permission of Penguin Books Ltd and Hatchett Book Group, Inc. 